\title{
Professor Dr. Martin Prozesky Publications (1965 - 2018)
}

\section{Scholarly Books}

[2018] Honest to Goodness. (Forthcoming from Wipf and Stock Publishers, Eugene, Oregon, USA, in their Resource Publications imprint.) This book provides the author's semi-autobiographical account of the scholarly work and personal experiences that lead him to differentiate between the classical Christianity of traditional, orthodox faith and what he calls an alternative Christianity that has been emerging since the pioneering work of Friedrich Schleiermacher, and why he considers the latter to be closer to the work and words of the Jesus of history.

2017. Warring Souls: When Religious Faith is Governed by Ethical Passion and When it Isn't. Johannesburg: Porcupine Press. (This is the author's first attempt at using fiction to explore the serious tensions between conservative and radical Christians in a fictitious, South African university setting.)

2007. Conscience: Ethical Intelligence for Global Well-Being. Pietermaritzburg: University of KwaZulu-Natal Press.

1996. Gandhi and South Africa: Principles and Politics. Pietermaritzburg \& New York: University of Natal Press \& St. Martin's Press. (Co-edited with Judith Brown.)

1995. Living Faiths in South Africa. Cape Town: David Philip Publishers. London \& New York: Hurst \& St. Martin's Press. (Co-edited with John de Gruchy; and author of the 'Introduction' and compiler of the appendices.)

1992. A New Guide to the Debate about God. London \& Pietermaritzburg: SCM \& University of Natal Press.

1991. A Southern African Guide to World Religions. Cape Town: David Philip. (Co-edited with John de Gruchy; and author of the 'Introduction' and compiler of the appendices.)

1990. Christianity Amidst Apartheid. London: Macmillan. Editor and author of 
the Introduction and one chapter. (SA edition: Christianity in South Africa, published by Southern Book Publishers Halfway House, 1990.) 1984. Religion and Ultimate Well Being: An Explanatory Theory. London \& New York: Macmillan \& St Martin's Press.

\section{Chapters in Edited Books}

2016. Universities, Cultural Diversity and Global Ethics: Opportunities for Moral Leadership. In Singh, Divya \& Christoph Stückelberger (eds.): Ethics in Higher Education: Values-Driven Leadership for the Future. Geneva: Globethics.net Education Ethics. Available at:

http://uir.unisa.ac.za/bitstream/handle/10500/21903/GE_Education_Ethi cs_1_isbn9782889311644\%20\%281\%29.pdf?sequence=1\&isAllowed=y 2012. Ethics for the Engineering Profession. In Management for Engineers, Technologists and Scientists. $3^{\text {rd }}$ Edition. Cape Town: Juta.

2009. Chapter 1: Cinderella, Survivor and Saviour: African Ethics and the Quest for a Global Ethic. In Murove, Munyaradzi Felix (ed.): African Ethics: An Anthology of Comparative and Applied Ethics. Pietermaritzburg: UKZN Press.

2009. Chapter 16: Well-Fed Animals and Starving Babies: Environmental and Developmental Challenges from Process and African Perspectives. In Murove, Munyaradzi Felix (ed.): African Ethics: An Anthology of Comparative and Applied Ethics. Pietermaritzburg: UKZN Press.

2009. Value Systems in South Africa. (Chapter coordinator and contributor.); and 'Case Study Using Ethical Skills and Insights. In Ethics for Accountants and Auditors. $2^{\text {nd }}$ Edition. Cape Town: Oxford University Press Southern Africa.

2006. Ethics, Spirituality and the Secular. In du Toit, Cornel W. \& Cedric P. Mayson (eds.): Secular Spirituality as a Contextual Critique of Religion. Pretoria: UNISA.

2001. 'Everything that rises must converge': Some Ideas for an Ethical Spirituality and for a Spiritually-enriched Ethic. In King, Ursula (ed.): Spirituality and Society in the New Millennium. Brighton: Sussex Academic Press.

2001. Response to Professor Sir Stewart Sutherland: 'Ethics and Values in Higher Education'. In Higher Education Lecture Series 2000. Pretoria: Ministry of Education, South Africa. 
2000. The Process Worldview as an Ethic in a World of Uneasy Pluralism, Incomplete Democratisation and Economic Injustice. In Cochrane, J.R. \& Bastienne Klein (eds.): Sameness and Difference: Problems and Potentials for Civil Society in South Africa. Washington DC: Center for Philosophy and Values.

1998. Faith, Praxis and Politics: South Africa from Gandhi to Desmond Tutu.

In King, Ursula (ed.): Faith and Praxis in a Postmodern Age. London, Cassell.

1989. Towards a Progressive, Social Approach to the Philosophy of Religion.

In Pillay, Gerald (ed.): The Future of Religion. Pretoria: Serva Publishers. 1988. Methodological Issues Arising from the Experience of Religion as Oppressive. In Mouton, Johann et al. (eds.): Paradigms and Progress in Theology. Pretoria: HSRC.

1985. Ultimate Well Being and the Heritage of Theism in Faith's New Age. In

Ker, John M. \& Kevin J. Sharpe (eds.): Religion and Change. Auckland. 1985. Judging Religion. In Sontag, F. \& J. Roth (ed.): The Defense of God. New York: Paragon House.

\section{Peer-reviewed Journal Articles}

2016. Honest to God and the South African Churches in 2016. Acta Theologica 36,1,June: 152-169.

2016. Ethical Leadership Resources in Southern Africa's Sesotho-speaking Culture and in King Moshoeshoe I. Journal of Global Ethics 12,1,April: 6-16. Available at:

https://www.researchgate.net/publication/299403404_Ethical_leadership _resources_in_southern_Africa\%27s_Sesotho-

speaking_culture_and_in_King_Moshoeshoe_I

2014. Homo Ethicus: Understanding the Human Nature that Underlies Human Rights and Human Rights Education. Journal for the Study of Religion 27,1: 283-301. (Special Edition in Honour of Cornelia Roux.) Available at: http://www.scielo.org.za/scielo.php?script=sci issuetoc\&pid=1011760120140001\&lng=en\&nrm=iso

2012. John Hick's Interpretation of Religion: A Perspective from South Africa.

Journal for the Study of Religion 25,1: 5-13. Available at: https://www.jstor.org/stable/pdf/24798117.pdf

2009. Is the Secular State the Root of our Moral Problems in South Africa? 
Published in Alternation Special Edition No. 3: 237-253. Available at: http://alternation.ukzn.ac.za/Files/docs/Alternation\%20Spec\%20Ed\%20 3\%20Pdfs/12\%20Prozesky\%20FIN[1].pdf

2009. The Scott Harker Model of Ethical Business Leadership in the Light of an African Understanding of Human Existence. African Journal of Business Ethics 4,1,November: 1-4. Available at:

http://ajobe.journals.ac.za/pub/article/view/60

2003. Ethics Education in the Accountancy Profession. Accountancy SA June: $2 \mathrm{ff}$.

2002. 'The soul of the future'. Faith and Freedom: A Journal of Progressive Religion 55,part 1,154,Spring and Summer.

2000. The Proselyization Problem: Principles, Practices and National Constitutions in South Africa. Emory International Law Review 14:849878.

2000. Well-fed Animals and Starving Babies: Environmental and Developments Issues in Process and African Perspectives. Concrescence: Australasian Journal of Process Thought 1,1,June. Electronic journal: www.alfred.north.whitehead.com

2000. From Creed to Conscience and The Constitution of South Africa. Available at: http://sof.org.nz/prozesky.htm

1999. Religion and the 1996 South African Constitution. Scriptura: International Journal of Bible, Religion and Theology in Southern Africa 69,1:103-110. Available at:

http://scriptura.journals.ac.za/pub/article/viewFile/1152/1092

1999. Ethics in Process Perspective. South African Journal of Philosophy 18,1:

1-17. Available at:

https://www.researchgate.net/publication/276888335_Ethics_in_process _perspective

1996. Academic and Religious Perspectives on Ethics and the Future. Journal for the Study of Religion 9,2,September: 3-20. Available at:

https://www.jstor.org/stable/pdf/24764177.pdf

1995. Staff Development and Evaluation at South African Universities. Journal of Education 20,: 41-45.

1995. Experientialist and Evidentialist Approaches to the Justification of Theism. Journal for the Study of Religion 8,2,September: 47-58. Available at: https://www.jstor.org/stable/pdf/24764008.pdf

1995. Religious Justice at Last? Believers and the New Constitution in South 
Africa. Journal of Theology of Southern Africa 92: 11 - 21.

1995. The Philosophical Anthropology of A.N. Whitehead. South African Journal of Philosophy 14,2,May:54-59.

1994. Gift or Delusion? A Reply to James Moulder's Logico-mysticism. South African Journal of Philosophy 13,1: 36 - 38.

1993. A Reply to Jan Platvoet. Numen Journal of the International Association for the History of Religions 40: 343-47.

1992. Towards a Criteriology of Religions. Journal for the Study of Religion 5,1,May: 67-77. Available at: https://www.jstor.org/stable/pdf/24764138.pdf

1991. The Challenge of Other Religions for Christianity in South Africa. Journal of Theology for Southern Africa 74:35-45.

1990. Human Rights and Concepts of Human Nature. Theoria 75,: 1-5.

1990. South Africa's Contribution to Religious Studies. Journal of Theology for Southern Africa 70,: 9-20.

1989. Is the Concept of Human Rights Logically Permissible in Theistic Religion? Journal for the Study of Religion 2,2,17-26. Available at: https://www.jstor.org/stable/pdf/24764092.pdf

1988. Explanations of Religion as Part of and Problem for Religious Studies. Religious Studies 24,:303ff. Available at:

https://www.jstor.org/stable/pdf/20019288.pdf?refreqid=excelsior\%3Ab 5546b35a9755249e3c6d9d24e2082f6

1988. Why did God Hold Back at Auschwitz? Review article on Albert Nolan's book God in South Africa: The Challenge of the Gospel. Cape Town: David Philip. Southern African Review of Books February/ March:14f.

1988. Historical Materialism and Theology. Review article on James Cochrane's book Servants of Power: The Role of English Speaking Churches 1903-1930. Johannesburg: Ravan Press. Southern African Review of Books December: pp7f.

1988. Review Article: Servants of Power. Journal for the Study of Religion 1,2,September: 77ff. (Not the same as the previous article.) Available at: https://www.jstor.org/stable/pdf/24764021.pdf

1986. Beyond Dialogue: Towards a Multicultural Transformation of Christianity and Buddhism: A Review Article. (with Felicity Souter Edwards). Journal of Theology for Southern Africa 56,: $67 \mathrm{ff}$.

1986. Philosophical Cosmology and Anthropology in the Explanation of Religion. Theoria 66,May: 29ff. 
1986. Philosophical Cosmology and Anthropology in the Explanation of Religion. Theoria 66,May: 29ff.

1986. Can Christians Overcome Apartheid? Journal of Theology for Southern Africa 54,March: 54:53 - 55.

1985. Is there a Place for the Criticism and Reformulation of Religion in Religious Studies? Religion in Southern Africa 5:71-81. Available at: https://www.jstor.org/stable/pdf/24763655.pdf

1985. A Critique of Theistic Religion. South African Journal of Philosophy 4: $55-61$.

1981. Christology and Cultural Relativity. Journal of Theology for Southern Africa 35,June: 44ff.

1981. The Divine Absentee: Karl Barth and the 'Death of God' Theologians. Theoria 57, October:39ff.

1981. The Young Schleiermacher: Advocating Religion to an Age of Critical Reason. Journal of Theology for Southern Africa 37: 50ff.

1980. Friedrich Schleiermacher's Earliest Account of Religious Experience. Religion in Southern Africa 1,2,July: 71ff. Available at:

https://www.jstor.org/stable/pdf/24763718.pdf

1979. Review of Process Theology: An Introductory Exposition, by John B. Cobb Jr. and David Ray Griffin. Journal of Theology for Southern Africa 26,March:76.

1977. The Emergence of Dutch Pietism. Journal of Ecclesiastical History 28: $29 \mathrm{ff}$.

1977. Context and Variety in Religious Language. Scottish Journal of Theology 29: $201 \mathrm{ff}$.

1975. Individualism and Conformity in Religion. Pro Veritate February: 23ff. 1975. Religious Authority and the Individual. Journal of Theology for Southern Africa 10: $17 \mathrm{ff}$.

1965. Decision for Discipleship. The Livingstonian 1,5: 38-40.

\section{Editorships}

Martin Prozesky was the founding editor of the official journal of the Association for the Study of Religion in Southern Africa (ARSA), the journal Religion in Southern Africa, which appeared twice a year from January 1980 till July 1987. Thereafter, it was renamed the Journal for the Study of Religion (in Southern Africa), and he continued as the Founding Editor, latterly with 
Professor Dr. Martin Prozesky Publications (1965 - 2018)

P.S. Maxwell as Executive Editor, until the end of 1998.

Religion in Southern Africa (1980 - 1987). Available at: https://www.jstor.org/journal/ reli soutafri

Journal for the Study of Religion (in Southern Africa) (1988 - the present) is available at: https:// www.jstor.org/journal/jstudyreligion and on

Scielo South Africa, since 2013, at:

http://www.scielo.org.za/scielo.php?script=sci serial\&pid=1011-7601

\section{Academic Reviews}

1994. Shots in the Street: Violence and Religion in South Africa, by David Chidester, 1991. Journal of Theology for Southern Africa 86, March: 9899.

1990. The Myth of Christian Uniqueness: Towards a Pluralistic Theology of Religions. Edited by John Hick and Paul F. Knitter. Maryknoll: Orbis, 1987. Journal of Theology for Southern Africa 71:81.

1990. Towards a Universal Theology of Religions. Edited by Leonard Swidler. Maryknoll: Orbis, 1987. Journal of Theology for Southern Africa 70:70.

1990. The Limits of Interpretation and of Religion. Review article of David Chidester's book Salvation and Suicide: An Interpretation of Jim Jones, the Peoples Temple and Jonestown. Bloomington and Indianapolis, Indiana University Press, 1988. Journal for the Study of Religion 3,1, March: 72-76. Available at:

https://www.jstor.org/stable/pdf/24764160.pdf

1989. The Road to Damascus. Kairos and Conversion. No authors given. Reality November 1989, 21,6: 19f.

1989. Darwinism and Divinity: Essays on Evolution and Religious Belief. Edited by John Durant. Oxford: Basil Blackwell. S.A. Journal of Philosophy 8,1,February: 60.

1989. From Athens to Jerusalem: The Love of Wisdom and the Love of God, by S.R.L. Clarke. SA Journal of Philosophy 8,1,February: 59.

1988. Understanding Modern Theology I: Cultural Revolutions and New Worlds, by Jeffery Hopper. Journal of Theology for Southern Africa 65, December: 87. 
1988. Friedrich Schleiermacher: Pioneer of Modern Theology. Edited by Keith W. Clements. Journal of Theology for Southern Africa 64, September: 78f.

1986. Circles of God: Theology and Science from the Greeks to Copernicus, by Harold P. Nebelsick. Journal of Theology for Southern Africa 56, September: 78-79.

1985. Miracles and the Critical Mind, by Colin Brown. Journal of Theology for Southern Africa 52, September: 75-76.

1982. 'A Partly Dissenting Postscript': Review of Taking Leave of God, by Don Cupitt. Journal of Theology for Southern Africa 39, June: 79 - 81.

1982. Towards a World Theology, by Wilfred Cantwell Smith. Religion in Southern Africa 3,2,July: 45-47. Available at:

https://www.jstor.org/stable/pdf/24763676.pdf

1981. God and the Secular, by Robin Attfield. Philosophical Papers x,1,May: 40-42.

1980. Aquinas: God and Action, by David B. Burrell. Philosophical Papers ix, 1,May: 47-48.

1979. Die Vinger van God. By Allan Boesak. Reality 11,6: $15 \mathrm{f}$.

1979. Process Theology: An Introductory Exposition, by John B. Cobb Jr. and David Ray Griffin. Journal of Theology for Southern Africa 26,March: 76.

1977. Tussen Pietisme en Reveil, by P.N. Holtrop. Journal of Ecclesiastical History 28: $235 \mathrm{f}$.

1975. Creation, by Claus Westermann. Journal of Theology for Southern Africa 12, September: 70.

1974. The Image of God in Man, by David Cairns. Journal of Theology for Southern Africa 9,December: 67.

1973. God the Problem, by Gordon D. Kaufmann. Journal of Theology for Southern Africa 4,September: 5962.

\section{Other Papers}

2003. 'A Guide to Research Ethics for Staff and Students'. Prepared for the University Ethics Committee, University of KwaZulu-Natal.

2003. 'A Short Guide to Sports Ethics'. Prepared for Sport and Recreation South Africa, Pretoria.

2003. 'Ethics for South African Rugby Stars', Chapter 4 in Winning the Game 
of Life, Life Skills Manual produced for contracted rugby players by the South African Rugby Football Union, Newlands, Cape Town.

2001. 'Ethics in the Education of South African Chartered Accountants'. Report presented to the South African Institute of Chartered Accountants, Johannesburg.

1992. Research Paper on 'The Concept of Freedom in Relation to Eastern and Western Thought'. Straniak Foundation, Switzerland.

1990. Research Report called 'Towards an Inclusive Philosophical Anthropology'. Pretoria: Human Sciences Research Council.

1989. Research Report on 'Religion and Human Rights: SA Law Commission Working Paper 25: Project 58: Group and Human Rights'.

\section{Other Publications}

Over 200 newspaper articles published to date.

\section{Non-academic Books}

2003. Frontiers of Conscience: Exploring Ethics in a New Millennium. Pietermaritzburg: Equinym Publishing.

1997. Soulscapes: A Book of Spiritual Explorations. (30 Short Articles.)

Pietermaritzburg: Tamarisk.

\section{Dissertations}

1976. A Critical Examination of the Pietistic Element in the Religious Philosophy of Friedrich Schleiermacher. Unpublished D.Phil. dissertation. University of Rhodesia, Salisbury.

\section{Student Dissertations (A Selection)}

\section{Master of Arts}

1999. Munyaradzi Felix Murove: The Shona Concept of Ukama and the Process Philosophical Concept of Relatedness with Special Reference to the Ethical Implications of Contemporary Neo-liberal Economic Practices. 
1982. James Massey: The Process Metaphysics of Alfred North Whitehead and its Expression in a Christian Pastoral Ministry.

1977. Ian Douglas Darby: Anglican Worship in Victorian Natal.

\section{Doctor of Philosophy}

2007. Domoka Lucinda Manda: The Importance of the African Ethic of

Ubuntu and Traditional Healing Systems for Black South African Women in the Context of HIV and AIDS.

1993. Alrah Llewellyn Major Pitchers: A Critical Examination of the Christology of Hans Küng.

1989. Roger John Cazziol: A Comparative Study of Christian Missions in Swaziland, 1845-1968.

1986. Robert Neville Richardson: Christian Community and Ethics: Critical Reflections on the Nature and Function of the Church in the Ethics of Stanley Hauerwas.

1983. Robert George Clarke: For God or Caesar: An Historical Study of Christian Resistance to Apartheid by the Church of the Province of South Africa 1946-1957.

1982. Ian Douglas Darby: The Soteriology of Bishop John William Colenso.

1978. Philip Higgs: The Unity of the Self and its Distinctiveness in the Writings of Reinhold Niebuhr and John Macmurray.

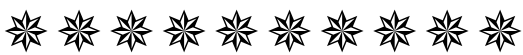

